\begin{tabular}{|c|c|c|}
\hline $\begin{array}{l}\square \text { Artikel Pengabdian } \\
\square \text { Info Artikel : }\end{array}$ & \begin{tabular}{|c|c|} 
OPEN & 0 \\
ACCES & $\odot$ \\
\end{tabular} & $\begin{array}{r}e-I S S N \text { : 2685-677X } \\
\text { http://www.jurnal.ummu.ac.id/index.php/BIOSAINSTEK }\end{array}$ \\
\hline $\begin{array}{l}\text { Diterima : } 29 \text { Des } 2021 \\
\text { Dipublikasi : } 20 \text { Jan } 2022\end{array}$ & Ciogogle & $\begin{array}{r}\text { Jurnal BIOSAINSTEK. Vol. } 4 \text { No. 1, 66-73 } \\
\text { DoI: https://doi.org/10.52046/biosainstek.v4i1.66-73 }\end{array}$ \\
\hline
\end{tabular}

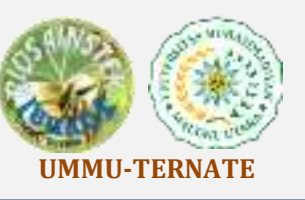

\title{
Jenis Produk Olahan Perikanan Unggulan Di Kota Ternate
}

\author{
M. Fatah Hi. Ambar ${ }^{1}$, Umar Tangke ${ }^{2}$, Syahnul S. Titaheluw ${ }^{2}$, dan Aisyah Bafagih ${ }^{2}$ \\ 1 Program Studi Teknologi Hasil Perikanan, Fakultas Pertanian, Universitas Muhammadiyah Maluku Utara, Ternate, \\ Indonesia. \\ 2 Staf Pengajar Program Studi Teknologi Hasil Perikanan, Fakultas Pertanian, Universitas Muhammadiyah Maluku Utara, \\ Ternate, Indonesia. \\ ${ }^{\square}$ Korespondensi : Umar Tangke, Universitas Muhammadiyah Maluku Utara, Ternate, Indonesia.
Email : umbakhaka@gmail.com
}

\begin{abstract}
ABSTRAK
Penelitian ini dilaksanakan selama 1 bulan dengan tujuan untuk menentukan produk olahan hasil perikanan unggulan di Kota Ternate. Metode dan prosedur pengambilan data yang dilakukan adalah survey, observasi lapangan dan wawancara yang kemudian dianalisis menggunakan metode skoring. Hasil penilitian didapat bahwa produk serundeng tuna merupakan produk olahan perikanan yang lebih unggul pertama di kota ternate berdasarkan hasil analisis menggunakan metode Bayes dengan kriteria nilai $\mathrm{A}_{1}=2$ (stok terbatas dan ada produk saingan), $A_{2}=2$ (bahan baku tersedia dan harga bahan baku tinggi), $A_{3}=2$ (bahan baku tambahan stabil dengan harga murah), $A_{4}=2$ (tenaga kerja banyak, kurang membutuhkan skill dan upah rendah), $A_{5}=2$ (Mudah dalam pengolahan, penyimpanan dan distribusi), $A_{6}=2$ (Tidak memerlukan teknologi khusus), $A_{7}=2$ (harga mahal), $A_{8}=2$ (ada nilai tambah dan keuntungan), $A_{9}=1$ (menghasilkan limbah yang banyak) dengan nilai gabung (NG) 1.90 kemudian produk unggulan kedua yaitu Abon Ikan Tuna dengan kriteria nilai $A_{1}=2$ (stok terbatas dan ada produk saingan), $A_{2}=2$ (bahan baku tersedia dan harga bahan baku tinggi), $A_{3}=1$ (bahan baku tambahan mahal dan ketersediaannya kontinu), $A_{4}=2$ (tenaga kerja banyak, kurang membutuhkan skill dan upah rendah), $\mathrm{A}_{3}=2$ (Mudah dalam pengolahan, penyimpanan dan distribusi), $A_{6}=2$ (Tidak memerlukan teknologi khusus), $A_{7}=2$ (harga mahal), $A_{8}=2$ (ada nilai tambah dan keuntungan), $A_{9}=1$ (menghasilkan limbah yang banyak) dengan nilai gabung $(\mathrm{NG}) 1.80$.
\end{abstract}

Keyword: Produk olahan, Produk Unggulan, Diversifikasi

\section{PENDAHULUAN}

\subsection{Latar Belakang}

Kota Ternate adalah sebuah kota yang berada di bawah kaki gunung api Gamalama pada sebuah Pulau Ternate di Provinsi Maluku Utara, Indonesia. Ternate menjadi satu kota otonom sejak 4 Agustus 2010, dan menjadi Ibu kota sementara Provinsi Maluku Utara sampai Sofifi yang menjadi ibukotanya di Pulau Halmahera siap secara infrastruktur. Secara geografis Kota Ternate terletak pada posisi $0^{\circ}-2^{\circ}$ Lintang Utara dan $126^{\circ}-128^{\circ}$ Bujur Timur dengan luas wilayah Kota Ternate adalah $5.795,4 \mathrm{~km}^{2}$ dan lebih didominasi olehwilayah laut 5.633,34 $\mathrm{km}^{2}$ sedangkan luasdaratan $162,069 \mathrm{~km}^{2}$ (Umanail dkk, 2016)

Persentase potensi sumberdaya ikan pelagis maupun dasar/demersal, Ikan pelagis merupakan salah satu bagian terpenting dari potensi sumberdaya perikanan laut di Indonesia dan merupakan bahan konsumsi dalam negeri. Sumberdaya perikanan laut tersebut perlu dijaga kelestariannya agar dapat dimanfaatkan secara terus menerus dan dapat juga dinikmati oleh generasi yang akan datang. Salah satu pertanyaan mendasar dalam pengelolaan sumberdaya ikan adalah bagaimana memanfaatkan sumberdaya tersebut sehingga menghasilkan manfaat ekonomi yang tinggi.

Kelimpahan sumberdaya perikanan, meningkatnya jumlah produksi perikanan tangkap menyebabkan tingginya jumlah hasil tangkapan, dan jika tidak dimanfaatkan akan terbuang karena rusak atau kemunduran mutu sehingga dilakukan diversifikasi produk. Diverfisikasi adalah Penganekaragaman Jenis produk olahan hasil perikanan dari bahan baku yang belum/sudah dimanfaatkan dengan tetap memperhatikan faktor-faktor mutu dan gizi, sebagai usaha penting bagi peningkatan konsumsi produk perikanan baik kualitas maupun kuantitas jenis produk dalam bentuk olah tradisinal maupunolahan modern. Usaha pengolahan hasil perikanan tradisional meliputi 
pemindangan, pengasinan/pengeringan, kerupuk dan olahan lainnya, dengan bahan baku yang berasal perikanan tangkap. Sedangkan usaha pengolahan hasil perikanan modern terdiri dari pembekuan udang dan value added, dengan bahan baku yang berasal dari perikanan budidaya (DKP Propinsi Maluku Utara, 2018).

Usaha pengolahan hasil perikanan merupakan istilah umum yang mendefinisikan penanganan pasca produksi tangkap atau panen budidaya menggunakan sarana prasarana dan teknologi. Tujuan pengolahan hasil perikanan adalah untuk meningkatkan nilai tambah terhadap produk perikanan, untuk mengawetkan ikan karena bersifat mudah rusak dan busuk (Bar, 2015) serta untuk komersial (Thrane et al., 2009). Usaha pengolahan hasil perikanan dilakukan sesuai dengan jenis komoditas ikan serta selera konsumen (Riyanto and Mardiansjah 2018). Untuk memenuhi selera konsumen yang beragam dan terus berkembang, dilakukan diversifikasi yaitu penganekaragaman produk olahan hasil perikanan. Dengan diversifikasi akan selalu ada alternative dan penyegaran menu, dengan demikian kejenuhan pasar dapat teratasi. Selain itu diversifikasi produk olahan hasil perikanan merupakan salah satu upaya meningkatkan daya serap pasar, atau dengan kata lain meningkatkan permintaan serta menciptakan alternatif lebih banyak bagi para pengolah hasil perikanan untuk mengembangkan usahanya (Agustini dan Swastawati, 2003).

Perbedaan karakteristik sumber daya ikan, sumber daya manusia, sumber daya teknologi di setiap daerah mengakibatkan potensi pengembangan usaha pengolahan hasil perikanan juga berbedabeda.Penting untuk mengidentifikasi potensi suatu wilayah dalam upaya pengembangan usaha pengolahan hasil perikanan. Dengan mengetahui potensi yang dimiliki, maka dapat dibuat strategi yang tepat guna mendorong pengembangan usaha pengolahan hasil perikanan yang sesuai. Strategi adalah cara penyusunan tindakan-tindakan yang dilakukan oleh pengelola perusahaan untuk mencapai misi, sasaran dan tujuan perusahaan. Salah satu strategi yang harus tepat adalah pemilihan produk olahan hasil perikanan yang akan dikembangkan (Najib dan Hubeis, 2008 dalam Ramli dkk, 2015).

Ditinjau dari jenisnya, hasil olahan ikan antara satu daerah dengan daerah lainnya berbedabeda tergantung dari sumberdaya yang terdapat di daerah tersebut yang pada hakekatnya meningkatkan nilai tambah bagi sektor perikanan secara menyeluruh (Salampessy et al., 2012). Pengembangan usaha pengolahan, diversifikasi dan distribusi hasil perikanan di Kota Ternate, masih mengalami kendala karena belum berkembangnya sentra pengolahan produk perikanan, dan belum adanya identifikasi serta kajian ilmiah tentang industri pengolahan produk perikanan unggulan di wilayah Kota Ternate.

\subsection{Tujuan dan Manfaat Penelitian}

Penelitian ini bertujuan untuk menentukan produk olahan hasil perikanan unggulan di Kota Ternate dengan menggunakan metode skoring, sedangkan manfaat dari penelitian ini adalah sebagai bahan informasi dan masukan kepada masyarakat, nelayan pengolah, pemerintah daerah dan akademisi untuk dalam usaha meningkatkan produk diversifikasi olahan perikanan.

\section{METODE PENELITIAN}

Penelitian ini dilaksanakan selama bulan April 2021 di Kota Ternate, Kecamatan Ternate Tengah, Provinsi Maluku Utara, dengan alat dan bahan yang gunakan dalam penelitian ini adalah alat tulis menulis, 1 unit computer, kamera digital dan kuisioner. Prosedur pengambilan data yang dilakukan dalam penelitian ini adalah survey, observasi lapangan dan wawancara langsung pada lokasi penelitian serta wawancara dengan pihak penjual yang diantaranya swalayan, minimarket, dan toko penjual oleh-oleh untuk mendapatkan data primer dan sekunder dalam penelitian.

Sumber data penelitian ini adalah data dan informasi dari responden melalui wawancara. Responden atau narasumber dipilih secara purposive berdasarkan peran dalam kelompok prinsip keaktifan pada kegiatan perikanan tangkap, dan pemerataan perwakilan usaha perikanan yang ada di Kota Ternate. Jumlah populasi pelaku perikanan aktif yang mengolah produk perikanan dan yang menjual, dengan besarnya sampel yang dijadikan objek penelitian ditentukan berdasarkan rumus Sloving diacu dalam Sugiyono (2016) dengan tingkat kesalahan 5\% sebesar 130 orang.

$n=\frac{N}{1+\left(N e^{2}\right)}$

Keterangan $n$ : jumlah sampel minimal, $N$ : jumlah populasi, $e$ : Eror margin/tingkat kesalahan 
Penentuan besar sampel dalam setiap kelompok nelayan menggunakan stratifikasi alokasi berimbang dengan rumus:

$$
\begin{aligned}
& n^{1}=\frac{N^{1}}{N} x n \\
& \text { Dimana: } \\
& n^{1}: \text { jumlah sampel dalam tiap kelompok } \\
& N^{1}: \text { jumlah populasi dalam tiap kelompok } \\
& N \text { : jumlah populasi } \\
& n \text { : besar ukuran sampel }
\end{aligned}
$$

Analisis data yang digunakan adalah menggunakan skoring dengan fungsi nilai sebagai standarisasi nilai untuk menentukan produk perikanan unggulan Penentuan produk perikanan unggulan digunakan metode skoring dengan fungsi nilai, yang bertujuan untuk standarisasi nilai. Nilai tertinggi dari hasil penggabungan analisis skoring dengan fungsi nilai menjadi patokan penentuan SDI unggulan berdasarkan rangking. Standarisasi dengan fungsi nilai dapat dilakukan dengan menggunakan rumus dari Mangkusubroto dan Trisnadi (1985) dalam Carles (2014) sebagai berikut:

Fungsi nilai dilakukan dengan persamaan :

$$
\begin{gathered}
V(x)=\frac{X i-x 0}{X a-X 0} \\
V(A)=\sum_{i=a}^{n} V i(x i)
\end{gathered}
$$

Dimana:

$\boldsymbol{V}(\boldsymbol{X})$ fungsi nilai dari variable $X, \boldsymbol{X} \boldsymbol{i}$ nilai Variable $X$ yang ke $-i, \boldsymbol{X}_{\mathbf{0}}$ nilai terendah pada kriteria $X, \boldsymbol{X}_{\boldsymbol{a}}$ nilai tertinggi pada kriteria $X, \boldsymbol{V}(\boldsymbol{A})$ fungsi nilai dari alternatif A, $\boldsymbol{V} \boldsymbol{i},(\boldsymbol{X} \boldsymbol{i})$ Fungsi nilai dari alternatif pada kriteria ke-I dan $i=a, b, c, d, n$ (jenis ikan).

\section{HASIL DAN PEMBAHASAN}

Penganekaragaman atau diversifikasi pangan merupakan salah satu usaha dalam meningkatkan konsumsi ikan masyarakat. Diversifikasi bertujuan untuk memenuhi selera konsumen yang beragam dan terus berkembang sehingga selalu ada alternatif dan penyegaran menu, dengan demikian kejenuhan pasar dapat teratasi (Ismanadji daSudari, 1985 dalam KKP, 2015). Penganekaragaman produk olahan hasil perikanan yang dalam hal ini dapat disebut "added value" yang dilakukan dengan menggunakan bahan baku ikan kemudian ditambahkan dengan beberapa bahan tambahan lain, seperti tepung (tapioka, terigu), telur, serta bumbu-bumbu seperti lada, bawang putih, bawang merah, serta bumbu lainya yang kesemuanya berfungsi sebagai penambah rasa dan aroma, sehingga produk tersebut memiliki nilai tambah.

Produk-produk tersebut dapat diolah baik secara tradisional maupun secara modern, dimana hasilnya akan memiliki kualitas dan kuantitas yang jauh lebih baik. Beberapa jenis produk "added value" yang dapat dikembangkan di masyarakat baik yang modern maupun produk olahan tradisional yang sudah dikenal luas maupun yang belum dalam bentuk produk diversifikasi produk perikanan di Kota Ternate seperti, bakso ikan, nugget ikan, fish stick, sosis ikan, kerupuk ikan, abon ikan, akan dibahas dalam penelitian ini.

\subsection{Jenis Diversifikasi Produk Perikanan di Kota Ternate \\ 4.1.1. Suntung garu rica}

Suntung garu rica (Gambar 1) adalah produk olahan dengan bahan utama adalah jenis sumberdaya perikanan laut dengan nama latin Loligo $s p$ dan nama Indonesia lebih dikenal dengan nama cumi-cumi. Produk diversifikasi suntung garu rica di produksi oleh Fala Tanawan Industri, yang beralamat di Kelurahan Maliaro, Kota Ternate dengan bentuk produk basah yang dikemas menggunakan alumunium foil dan berat produk per kemasan sebesar $100 \mathrm{~g}$. Harga jual produk suntung garu rica adalah Rp. 35.000,- per kemasan dengan areal pemasaran di masih dilingkup wilayah Kota Ternate dan umur simpan produk rata-rata mencapai 4 - 5 bulan.

\subsubsection{Serundeng Tuna}

Serundeng Tuna (Gambar 2), adalah produk olahan dengan bahan utama adalah jenis sumberdaya perikanan laut dengan nama latin Thunus albacares. Produk diversifikasi Serundeng Tuna di produksi oleh PT Baroqah dua Putra, yang beralamat di Jl Gemini no 84 Kelurahan Ubo-ubo, Kota Ternate 
dengan bentuk produk kering yang dikemas menggunakan stendin post (plastic)dan berat produk per kemasan sebesar 100 g. Harga jual produk Serundeng Tuna adalah Rp. 23.000,- per kemasan dengan areal pemasaran di masih dilingkup wilayah Kota Ternate dan umur simpan produk rata-rata mencapai 6-7 bulan.

\subsubsection{Sambal Goreng Ikan Teri}

Sambal Goreng Ikan Teri adalah produk olahan dengan bahan utama adalah jenis sumberdaya perikanan laut dengan nama latin Stolephorus Sp. Produk diversifikasi di Sambal Goreng Ikan Teri produksi oleh Mekar Jaya Tober, yang beralamat di Kelurahan Tobololo, Kota Ternate dengan bentuk produk basah yang dikemas menggunakan Almunium foil dan berat produk per kemasan sebesar 100 g. Harga jual produk Sambal Goreng Ikan Teri adalah Rp. 23.000,- per kemasan dengan areal pemasaran di masih dilingkup wilayah Kota Ternate dan umur simpan produk rata-rata mencapai 6-7 bulan.

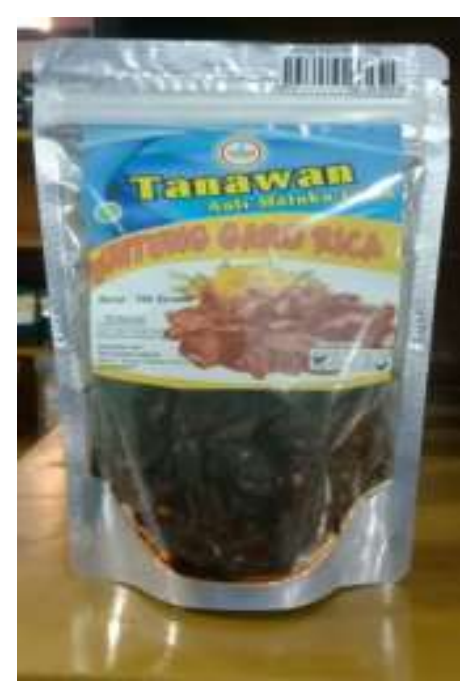

Gambar 1. Produk Suntung Garu Rica

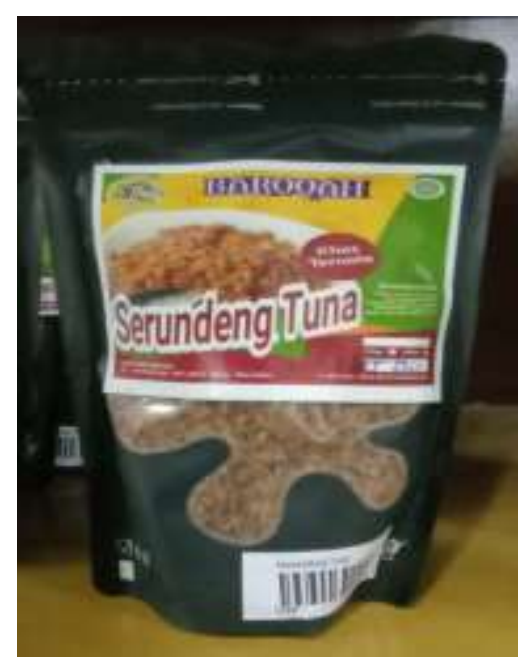

Gambar 2. Produk Serundeng Tuna

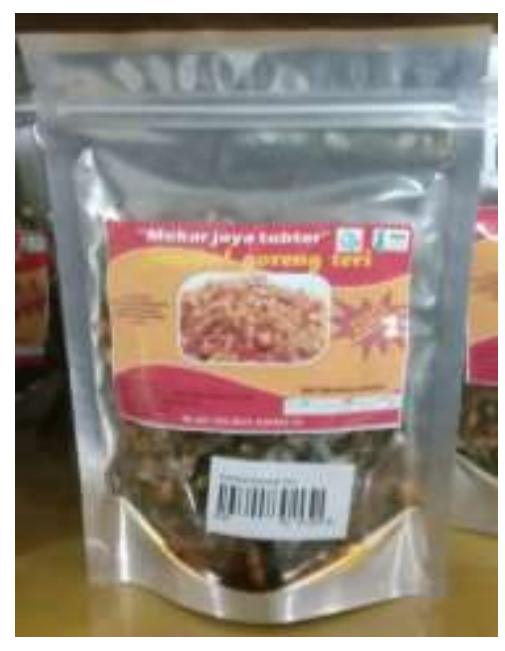

Gambar 3. Produk Sambal Goreng Ikan Teri

\subsubsection{Teri Rica-rica}

Teri Rica-rica (Gambar 4) adalah produk olahan dengan bahan utama adalah jenis sumberdaya perikanan laut dengan nama latin Stolephorus Sp. Produk diversifikasi di Teri Rica-rica produksi oleh Fagogoru Home Industri, yang beralamat di Kelurahan Tobololo, Kota Ternate dengan bentuk produk basah yang dikemas menggunakan toples plastic dan berat produk per kemasan sebesar $250 \mathrm{~g}$. Harga jual produk Teri Rica-rica adalah Rp. 50.000,- per kemasan dengan areal pemasaran di masih dilingkup wilayah Kota Ternate dan umur simpan produk rata-rata mencapai 4 bulan.

\subsubsection{Abon Ikan Tuna}

Abon Ikan Tuna (Gambar 5) adalah produk olahan dengan bahan utama adalah jenis sumberdaya perikanan laut dengan nama latin Thunus albacore dan nama Indonesia lebih dikenal dengan Tuna Sirip Kuning. Produk diversifikasi Abon Ikan Tuna di produksi oleh Industri Rumah Tangga MM. Hanum, yang beralamat di Jl Kayu Manis Kelurahan Tabahawa, Kota Ternate dengan bentuk produk kering yang dikemas menggunakan stendin post (plastic) dan berat produk per kemasan sebesar 150 g. Harga jual produk Abon Ikan Tuna adalah Rp. 46.000,- per kemasan dengan areal pemasaran di masih dilingkup wilayah Kota Ternate dan umur simpan produk rata-rata mencapai 6-7 bulan.

\subsubsection{Teri Kriuk}

Teri Kriuk adalah produk olahan dengan bahan utama adalah jenis sumberdaya perikanan laut dengan nama latin Stolephorus Sp. Produk diversifikasi di Teri Kriuk produksi oleh Home Industri Rumah Tangga Ne Gam Macahaya, yang beralamat di Kelurahan Malikrubu, Kota Ternate dengan bentuk produk kering yang dikemas menggunakan Almunium foil dan berat produk per kemasan sebesar100 g. Harga jual produk Teri Kriuk adalah Rp. 29.000,- per kemasan dengan areal pemasaran di masih dilingkup wilayah Kota Ternate dan umur simpan produk rata-rata mencapai 10 bulan.

\subsubsection{Ikan Garo Rica}

Ikan Garo Rica (Gambar 7) adalah produk olahan dengan bahan utama adalah jenis sumberdaya perikanan laut dengan nama latin Katsuwonus pelamis dan nama Indoneia lebih dikenal dengan 
cakalang. Produk diversifikasi Ikan Garo Rica di produksi oleh Ne Gam Macahaya Home Industri, yang beralamat di Jl Cengkeh Afo Kelurahan Malikrubu, Kota Ternate dengan bentuk produk basah yang dikemas menggunakan stendin post (plastic) dan berat produk per kemasan sebesar $150 \mathrm{~g}$. Harga jual produk Ikan Garo Rica adalah Rp. 41.000,- per kemasan dengan areal pemasaran di masih dilingkup wilayah Kota Ternate dan umur simpan produk rata-rata mencapai 6-7 bulan.

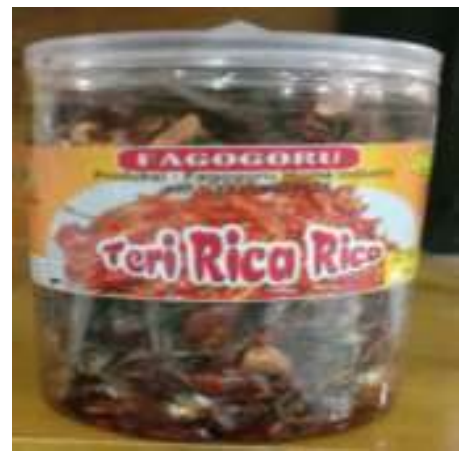

Gambar 4. Produk Teri Ricarica

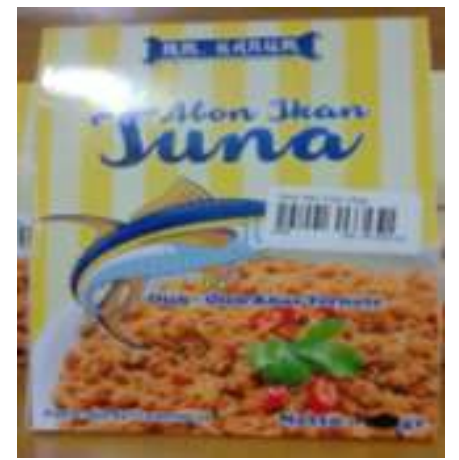

Gambar 5. Produk Abon Ikan Tuna

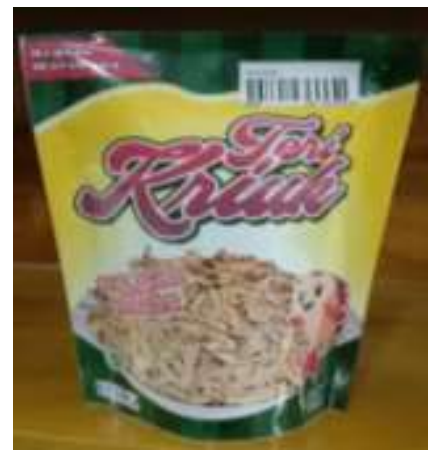

Gambar 6. Produk Teri Kriuk

\subsubsection{Dabu-Dabu Ikan Roa}

Dabu-Dabu Ikan Roa (Gambar 8) adalah produk olahan dengan bahan utama adalah jenis sumberdaya perikanan laut dengan nama latin Hemiramphus brasiliensis dan nama Indonesia lebih dikenal dengan Ikan Julung-julung Produk diversifikasi Dabu-dabu Ikan Roa diproduksi oleh Ummi Habibie Home Industri, yang beralamat di Kelurahan Tabahawa, Kota Ternate dengan bentuk produk basah yang dikemas menggunakan toples plastic dan berat produk per kemasan sebesar $200 \mathrm{~g}$. Harga jual produk Dabu-dabu Ikan Roa adalah Rp. 38.000,- per kemasan dengan areal pemasaran di masih dilingkup wilayah Kota Ternate dan umur simpan produk rata-rata mencapai 10 bulan.

\subsubsection{Teri Crispy}

Teri Cripy (Gambar 9) adalah produk olahan dengan bahan utama adalah jenis sumberdaya perikanan laut dengan nama latin Stolephorus Sp. Produk diversifikasi Teri Crispy diproduksi oleh Fala Tanawan Indusri, yang beralamat di Kelurahan Maliaro, Kota Ternate dengan bentuk produk basah yang dikemas menggunakan Almunium foil dan berat produk per kemasan sebesar 85 g. Harga jual produk Teri Crispy adalah Rp. 38.000,- per kemasan dengan areal pemasaran di masih dilingkup wilayah Kota Ternate dan umur simpan produk rata-rata mencapai 6-7 bulan.

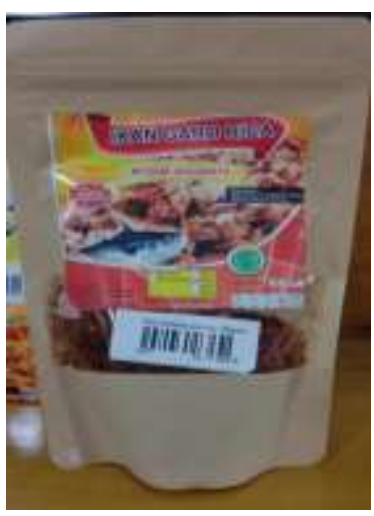

Gambar 7. Produk Ikan Garo Rica

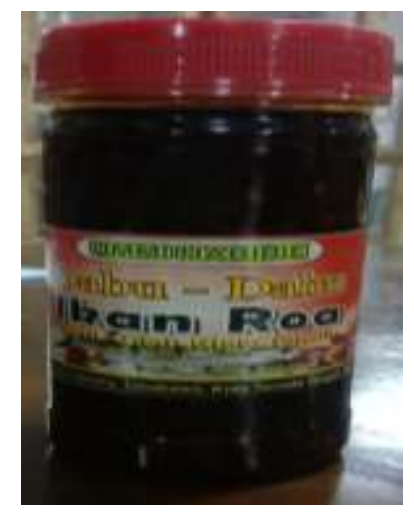

Gambar 8. Produk Dabudabu Ikan Roa

\subsubsection{Sambal Nyaao Ture}

Sambal Nyao Ture adalah produk olahan dengan bahan utama adalah jenis sumberdaya perikanan laut dengan nama latin Hemiramphus brasiliensis dan nama Indonesia lebih dikenal dengan Ikan Julung-julung Produk diversifikasi Sambal Nyao Ture diproduksi oleh Ne Gam Macahaya, yang beralamat di Kelurahan Malikrubu, Kota Ternate dengan bentuk produk basah yang dikemas menggunakan toples plastic dan berat produk per kemasan sebesar 200 g. Harga jual produk Sambal 
Nyao Ture adalah Rp. 34.500.,- per kemasan dengan areal pemasaran di masih dilingkup wilayah Kota Ternate dan umur simpan produk rata-rata mencapai 4 bulan.

\subsection{Produk Olahan Perikanan Unggulan di Kota Ternate}

Upaya pembangunan ekonomi daerah dapat dilakukan dengan inventarisasi potensi daerah agar dapat ditetapkan kebijakan pola pengembangan baik secara sektoral maupun secara multisektoral. Salah satu langkah inventarisasi potensi ekonomi daerah adalah dengan menginventarisasi produk-produk potensial, andalan dan unggulan daerah tiap-tiap sub sektor terutama sub sector perikanan dari tingkat Kota sampai Propinsi. Produk unggulan daerah menggambarkan kemampuan daerah menghasilkan produk, menciptakan nilai, memanfaatkan sumber daya secara nyata, memberi kesempatan kerja, mendatangkan pendapatan bagi masyarakat maupun pemerintah, memiliki prospek untuk meningkatkan produktivitas dan investasinya. suatu produk dapat dikatakan unggul jika memiliki daya saing sehingga mampu untuk menangkal produk pesaing di pasar domestik dan/atau menembus pasar ekspor.

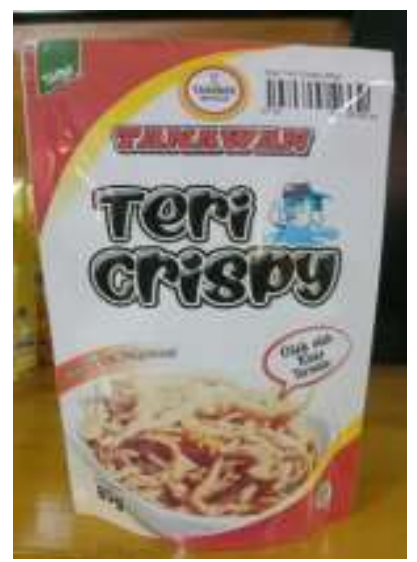

Gambar 9. Produk Teri Crispy

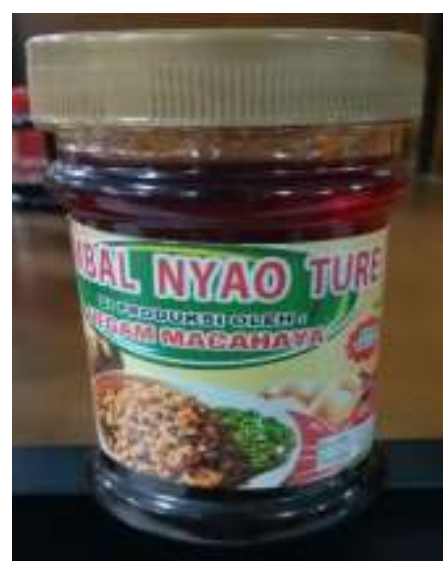

Gambar 10. Produk Sambal Nyao Ture

Menurut Ramli dkk (2018), Perbedaan karakteristik sumber daya ikan, sumber daya manusia, sumber daya teknologi di setiap daerah mengakibatkan potensi pengembangan usaha pengolahan hasil perikanan juga berbeda-beda. Penting untuk mengidentifikasi potensi suatu wilayah dalam upaya pengembangan usaha pengolahan hasil perikanan. Dengan mengetahui potensi yang dimiliki, maka dapat dibuat strategi yang tepat guna mendorong pengembangan usaha pengolahan hasil perikanan yang sesuai. Strategi adalah cara penyusunan tindakan-tindakan yang dilakukan oleh pengelola perusahaan untuk mencapai misi, sasaran dan tujuan perusahaan.

Kriteria yang menjadi dasar dalam analaisis untuk menentukan produk olahan hasil perikanan unggulan di modifikasi dari Ramli dkk (2018), meliputi ketersedian dan persaingan pasar $\left(\mathrm{A}_{1}\right)$, kontinyuitas dan harga bahan baku utama (ikan) $\left(A_{2}\right)$, ketersediaan dan harga bahan baku pembantu dan bahan produksi lainnya $\left(A_{3}\right)$, ketersedian, kemampuan dan upah tenaga kerja $\left(A_{4}\right)$, kemudahan dalam mengolah, menyimpan dan mendistribusikan $\left(A_{5}\right)$, ketersediaan dan kemampuan akases terhadap teknologi $\left(A_{6}\right)$, harga dan daya beli $\left(A_{7}\right)$ nilai tambah dan keuntungan $\left(A_{8}\right)$ dan limbah yang dihasilkan $\left(\mathrm{A}_{9}\right)$. Sedangkan produk olahan hasil perikanan sebagai alternatif dalam menentukan produk olahan hasil perikanan unggulan di lokasi penelitian yakni lokasi penjualan produk khas atau oleh-oleh Taranoate di Kota Ternate adalah produk olahan hasil perikanan yang sudah berkembang di Kota Ternate dan berpotensi besar di terima oleh pasar di Kota Ternate Propinsi Maluku Utara, diantaranya suntung garu rica, serundeng tuna, sambal goreng ikan teri, teri rica-rica, abon ikan tuna, teri kriuk, ikan garo rica, dabu-dabu ikan roa, teri crispy, sambal nyaao ture.

Hasil analisis sumberdaya ikan pelagis unggulan dapat dilihat pada Tabel 2. Berdasarkan Tabel 2 penilaian produk olahan perikanan unggulan, menempatkan produk serundeng tuna menjadi produk unggulan pertama dengan nilai gabungan (NG) 1.90, yang kemudian disusul oleh produk abon ikan tuna dengan nilai gabungan 1.80, suntung garu rica dan sambal gorang ikan teri dengan nilai gabungan 1.75, ikan garu rica, teri rica-rica dan teri kriuk, dabu-dabu ikan roa dengan nilai gabungan 
1.65 serta teri crispy pada posisi 6 dengan niali gabungan 1.55 dan sambal nyaao ture pada posisi ke 7 dengan nilai gabungan 1.45 .

Nilai gabung (NG) produk olahan ikan serundang tuna memiliki kriteria ketersiediaan stok yang terbatas dan tidak memiliki produk saingan lainnya, bahan baku tersedia dan harga bahan baku tinggi, Bahan baku tambahan stabil dengan harga murah, Tenaga kerja banyak, kurang membutuhkan skil dan upah rendah, Mudah dalam pengolahan, penyimpanan dan distribusi, tidak memerlukan teknologi khusus, Harga mahal yang mempengaruhi nilai tambah dan keuntungan serta kurang menghasilkan limbah dala proses pegolahan.

Tabel 2. Hasil Analisis Produk Olahan Perikanan Unggulan di Kota Ternate Menggunakan Metode Bayes

\begin{tabular}{|c|c|c|c|c|c|c|c|c|c|c|c|c|}
\hline \multirow{2}{*}{ No } & \multirow{2}{*}{ Jenis Produk } & \multicolumn{9}{|c|}{ Kriteria Penilaian } & \multirow{2}{*}{ NG } & \multirow{2}{*}{$\mathbf{R}$} \\
\hline & & $\mathbf{A}_{1}$ & $\mathbf{A}_{2}$ & $\mathbf{A}_{3}$ & $\mathbf{A}_{4}$ & $\mathbf{A}_{5}$ & $\mathbf{A}_{6}$ & $\mathbf{A}_{7}$ & $\mathbf{A}_{8}$ & A9 & & \\
\hline 1 & Suntung garu rica & 2 & 1 & 2 & 2 & 2 & 2 & 2 & 2 & 1 & 1.75 & 3 \\
\hline 2 & Serundeng tuna & 2 & 2 & 2 & 2 & 2 & 2 & 2 & 2 & 1 & 1.90 & 1 \\
\hline 3 & $\begin{array}{l}\text { Sambal goreng } \\
\text { ikan teri }\end{array}$ & 2 & 1 & 2 & 2 & 2 & 2 & 2 & 1 & 2 & 1.75 & 3 \\
\hline 4 & Teri rica-rica & 1 & 1 & 2 & 2 & 2 & 2 & 2 & 1 & 2 & 1.65 & 5 \\
\hline 5 & Abon ikan tuna & 2 & 2 & 1 & 2 & 2 & 2 & 2 & 2 & 1 & 1.80 & 2 \\
\hline 6 & Teri kriuk & 2 & 1 & 2 & 2 & 2 & 2 & 1 & 1 & 2 & 1.65 & 5 \\
\hline 7 & Ikan garo rica & 2 & 2 & 1 & 2 & 1 & 2 & 2 & 1 & 2 & 1.70 & 4 \\
\hline 8 & $\begin{array}{l}\text { Dabu-dabu ikan } \\
\text { roa }\end{array}$ & 2 & 1 & 2 & 2 & 2 & 2 & 1 & 1 & 2 & 1.65 & 5 \\
\hline 9 & Teri crispy & 1 & 1 & 2 & 2 & 2 & 2 & 1 & 1 & 2 & 1.55 & 6 \\
\hline \multirow[t]{2}{*}{10} & Sambal nyaao ture & 1 & 1 & 2 & 2 & 2 & 2 & 1 & 1 & 1 & 1.45 & 7 \\
\hline & Kriteri Bobot & 0.1 & 0.15 & 0.1 & 0.15 & 0.1 & 0.1 & 0.1 & 0.1 & 0.1 & & \\
\hline
\end{tabular}

\section{PENUTUP}

Hasil penilitian didapat bahwa produk serundeng tuna merupakan produk olahan perikanan yang lebih unggul pertama di kota ternate berdasarkan hasil analisis menggunakan metode Bayes dengan kriteria nilai $A_{1}=2$ (stok terbatas dan ada produk saingan), $A_{2}=2$ (bahan baku tersedia dan harga bahan baku tinggi), $A_{3}=2$ (bahan baku tambahan stabil dengan harga murah), $A_{4}=2$ (tenaga kerja banyak, kurang membutuhkan skill dan upah rendah), $A_{5}=2$ (Mudah dalam pengolahan, penyimpanan dan distribusi), $A_{6}=2$ (Tidak memerlukan teknologi khusus), $A_{7}=2$ (harga mahal), $A_{8}=$ 2 (ada nilai tambah dan keuntungan), $A_{9}=1$ (menghasilkan limbah yang banyak) dengan nilai gabung (NG) 1.90 kemudian produk unggulan kedua yaitu Abon Ikan Tuna dengan kriteria nilai $A_{1}=2$ (stok terbatas dan ada produk saingan), $A_{2}=2$ (bahan baku tersedia dan harga bahan baku tinggi), $A_{3}=1$ (bahan baku tambahan mahal dan ketersediaannya kontinu), $\mathrm{A}_{4}=2$ (tenaga kerja banyak, kurang membutuhkan skill dan upah rendah), $A_{3}=2$ (Mudah dalam pengolahan, penyimpanan dan distribusi), $\mathrm{A}_{6}=2$ (Tidak memerlukan teknologi khusus), $A_{7}=2$ (harga mahal), $A_{8}=2$ (ada nilai tambah dan keuntungan), $A_{9}=1$ (menghasilkan limbah yang banyak) dengan nilai gabung (NG) 1.80 .

\section{DAFTAR PUSTAKA}

Agustini, T.W. dan F. Swastawati. 2003. Utilization of fishery product with added value to support food diversification. Jurnal teknologi dan industri pangan. Vol. XIV (1) : 74-8.

Badrudin, Aisyah. (2011). Kelimpahan Stok Sumberdaya Ikan Demersal di Perairan Sub Area Laut Jawa. (Badrudin, et al.) Vol. 17 (1): 11-21.

Bar, E. S. 2015. A case study of obstacles and enablers for green innovation within the fish processing equipment industry. Journal of Cleaner Production, 90 (1): 234-243.

Cahyana A. 2001. Profil Produk Unggulan Daerah. Kabupaten Purbalingga. 
[DKP] Dinas Kelautan dan Perikanan Provinsi Maluku Utara. 2018. Laporan Tahunan 2018. Propinsi Maluku Utara.

[KKP] Kementerian Kelautan dan Perikanan. 2015. Modul Membuat Diversifikasi Produk Perikanan. Pusat Pendidikan Kelautan dan Perikanan. Badan Pengembangan SDM dan Pemberdayaan Masyarakat Kelautan dan Perikanan. Kementerian Kelautan dan Perikanan. Jakarta. Indonesia.

Nurasya Saimima Kementrian Kelautan Dan Perikanan Badan Pengembangan SDM - KP.2015. Pusat Pendidikan Kelautan dan Perikanan Jakarta, Desember 2015.

Ramli, Budi Setiawan, Imam Santoso, Siti Asmaul Mustaniroh. 2018. Penentuan Produk Olahan Hasil Perikanan Unggulan Berbasis Pesantren Menggunakan Metode Fuzzy Topsis. Samakia: Jurnal Ilmu Perikanan Vol. 9 (2): 53-64.

Riyanto, S., and F. H. Mardiansjah. 2018. Study of fisheries industry development in the local economic development in pati regency. Jurnal Pembangunan Wilayah dan Kota. 14(1) : 61-69.

Saanin, H. 1984. Taksonomi dan Kunci identifikasi Ikan. Jilid I dan II. Bina Cipta. bandung.

Salampessy, R.B.S., A. Permadi, dan J. Haluan. 2012. Kajian analisis pengembangan pengolahan hasil perikanan di Kabupaten Serang. Jurnal Ilmu Pertanian dan Perikanan. Departemen Pemanfaatan Sumberdaya Perikanan Fakultas Perikanan dan Ilmu Kelautan IPB. Bogor. Vol 1 (1) : 9-1.

Sugiyono. 2010. Metode Penelitian Pendidikan Pendekatan Kuantitatif, kualitatif, dan R\&D. Bandung: Alfabeta.

Septifitri. Dkk 2009. Analisis Kebutuhan Sarana Perikanan Dalam Rangka Pengembangan Perikanan Tangkap Berbasis Komoditas Tangkap Unggulan Dipropinsi Sumatra Selatan. Jurnal Saintek Perikanan. Vol. 5 (2): 8-13.

Thrane.M., E. H. Nielsen \& P. Christensen. 2009. Cleaner production in Danish fish processingexperiences, status and possible future strategies. Journal of Cleaner Production, 17(3): 380-390. 